Saja Albliwi,

Ph.D., King Abdulaziz University, Jeddah, Saudi Arabia

ORCID ID, 0000-0003-4360-0543

email: Salbliwi@kau.edu.sa

Leenah A. Alsolami,

King Abdulaziz University, Jeddah, Saudi Arabia

(iD) ORCID ID, 0000-0002-7489-1286

email: leenah.alsolami@gmail.com

Correspondence author: Salbliwi@kau.edu.sa

\title{
WILLINGNESS TO USE E-COMMERCE DURING CORONAVIRUS PANDEMIC IN SAUDI ARABIA
}

Abstract. The traditional retail market has been declining in recent years, while e-retailing has grown at an accelerated rate during the COVID-19 pandemic's lockdown era. The main purpose of the research is to look at the effect of the coronavirus outbreak on the shifting trends of electronic commerce (e-commerce) in Saudi Arabia. The authors investigate the impacts of factors derived by COVID-19 had on the e-commerce market. One hundred sixty individuals operating in e-commerce in the private sector in Saudi Arabia completed a self-administered questionnaire, including demographic information and three sections of five scale questions that meet the study's objectives. Most participants were males (66.2\%), $56.2 \%$ were aged between 30 and 40 years old, $38.75 \%$ had $5-10$ years of experience in the private sector, $40.6 \%$ worked in companies with more than 500 employees, and $43.0 \%$ of them from lives in Riyadh. The weighted average of the 1st section is $3.19 \pm 0.75$, indicating that the trend of the establishment of whether lack of alternatives has a positive implication on the intent of using e-commerce during the COVID-19 pandemic is "Neutral». The weighted average of the 2 nd section is $3.43 \pm 1.17$, which indicates the trend of determining whether the perceived ease of use has a positive implication on the adoption intent of consumers using e-commerce during a COVID-19 outbreak is «Agree». The weighted average of the 3rd section is $3.29 \pm 0.90$, which indicates the trend of exploring the underlying factors that leads to losses for many businesses during the crisis is «Neutral». Furthermore, the highest percentage of participants (56.2\%) mentioned that their company was not prepared for another lockdown. The research results could be useful for further analysis of different domains of the ecommerce market that developed during the pandemic. They could be utilized for examining opinions about ecommerce and whether the public wanted to switch from offline to online mode of marketing

Keywords: e-commerce, COVID-19, consumers, market, Saudi Arabia.

Introduction. Quarantine during COVID-19 affected consumer behavior in Saudi Arabia and across the globe. The productive economic activities in Saudi Arabia registered a downward trend because more than 37 million individuals in different regions were quarantined (Market Watch, 2020). By March 2020, the government introduced a lockdown in the capital Riyadh and the holy cities of Medina and Makkah. The international flights were also suspended for a long time. The risk for infection, virtual working arrangements, and lockdowns shifted consumer behavior to electronic commerce (e-commerce). These changes would stay for the years to come. E-commerce, which is «the practice of transacting business using the internet, the web, smartphone applications and browsers on mobile and computers», experienced rapid growth (Havrlant et al., 2021).

Digital allowed commercial transactions between and among organizations and individuals to be more formal (Alflayyeh and Belhaj, 2020). One leading company, Bin Dawood Holding, registered an increase in the average sales by $200 \%$ (Salem and Nor, 2020). The installation of its mobile applications rose by $400 \%$. The value of e-commerce would increase to 24 billion dollars (Illankoon, 2020).

Cite as: Albliwi, S., \& Alsolami, L. A. (2021). Willingness to Use E-Commerce During Coronavirus Pandemic in Saudi Arabia. Marketing and Management of Innovations, 4, 68-78. http://doi.org/10.21272/mmi.2021.4-06 
The pandemic outbreak has caused the rapid development of technology and increased its applications. E-commerce has an impact on many distribution costs. It affects the shape of markets, the movement of entities within these markets, and the competitive form (Villa et al., 2018). Such new changes and the evolving market have attracted the attention of researchers to dig out to what extent e-commerce marketing could bloom, what conditions it needs, and what consequences it could bring. Despite the advantages of e-commerce, it has notable drawbacks and encounters in local markets, where the capacities of transnational and multinational corporations are more, leading to the inability of national companies to continue.

Literature Review. The outbreak of COVID-19 accelerated the rise of e-commerce in Saudi Arabia. There was a change in consumer behavior whereby the consumers reported a significant increase in their interest in online pharmacy and grocery purchases during the pandemic (Salem and Nor, 2020; Habib and Hamadneh, 2021). Besides, elevation in communication technologies and employing information has enabled more spatiotemporal flexibility for people to buy through the evolution of online shopping (Vasić et al., 2019). As a novel and hopeful channel, e-commerce has attracted the attentiveness of marketing scholars concerning efforts to find incorporated schemes for deploying multiple channels (Dholakia et al., 2010; Melis et al., 2015). Dissimilar to the other e-activities as working online, e-commerce is a more complex phenomenon that may be attributed to the variety of products with different qualities (Schmid and Axhausen, 2019; Feichtinger and Gronalt, 2021; Le et al., 2021).

The e-commerce market in Saudi Arabia has experienced remarkable growth, with an increased turnover rate of $11 \%$ (Villa et al., 2018). The Saudi Arabia e-commerce market is the biggest in the entire Middle East and North Africa (MENA) region. It will continue to grow in the coming years. More than 6.34 million users are expected to continue to shop online, which will increase the number of individuals that are shopping online to 19.28 million by the year 2022 (Ezzi, 2016). This remarkable growth in online shoppers and turnover means that Saudi Arabia will overtake the UAE, which is currently the top ecommerce marketplace in the Middle East (Illankoon, 2020).

The COVID - 19 crisis expedited an expansion of e-commerce towards new enterprises, types of products, and customers. The customers in Saudi Arabia could presently access different commodities in the safety and convenience of their homes. Online shopping has continued to operate despite the restriction of contact (Al-mani, 2020). For battling the public health emergency of international attention announced by $\mathrm{WHO}$, a series of recommendations and interventions at different degrees to reduce physical interactions between people have been issued (Dryhurst et al., 2020; WHO, 2020; Manh et al., 2021). Therefore, people have been elevated the employ of ICT to implement e-shopping and daily activities (Barnes, 2020; López Soler et al., 2021). Purchasing size of e-commerce for June 2020 increased by $31 \%$, relative to the same month in 2019 ( $\mathrm{ACl}, 2020)$. Many hypermarkets and supermarkets had to deal with a massive request by adopting online queues or occupation their online shopping websites down (Pantano et al., 2020)

Additionally, dramatically reducing the revenue for the retailers triggers the stores to expand or shift their presence online and increase their capacity to process contactless and cashless payments, making most of the consumers go online (Koch et al., 2020). These transformations in the business and consumer behavior established a stage for a longstanding shift in how business is carried out all through the region (Illankoon, 2020). The retail sector was already undergoing challenging changes during the lockdown, and this has robust implications for the industry's footprints in the years to come (Grashuis et al., 2020). The movement of the customers was limited to pharmacies, hypermarkets, and supermarkets, which were the only facilities permitted to trade (Hoq, 2020). Nonetheless, during a partial lockdown, there was an exponential growth in electronic retailing, even though the purchases were conducted by clients centered on priorities that encompassed nutritional items and food essentials. These included cooking oil, dinner, 
frozen snacks, non-alcoholic drinks, fast mixes, and supplements, as well as health spending. Additionally, the grocery business experienced a spike when they made more than 4 times the profit (Illankoon, 2020).

Recently, Nguyen et al. (2021) revealed that information of 355 participants, collected during the social distancing period, was collected to determine the factors related to e-shopping for some products such as clothing, electronics, food, medications, and books). The results revealed that most of the participants $(80 \%)$ implicated e-shopping considerably than they usual before the outbreak of COVID-19. Completely working online had a positive correlation with e-shopping for electronics. Scare of disease encouraged eshopping higher frequencies for medications and food.

This study aimed to expound on the implications of COVID-19 on the e-commerce market in Saudi Arabia and looked at the factors that influence people's willingness to use e-commerce during the Coronavirus pandemic in Saudi Arabia.

Methodology and research methods. The descriptive design was chosen for this study, which helps determine the actual relationships between dependent and independent variables. The target population is individuals working in e-commerce businesses, entrepreneurs, and employees in the private sector in Saudi Arabia. The study sampling technique was probability or representative random sampling, which is widely used in survey-based research and assists the researchers in gaining an overview and making clear interpretations about a population. This study used primary data obtained for the first time exclusively for research purposes through self-administered questionnaire inanition to secondary data. An openended questionnaire through Google Forms was used, distributed by sharing the link on the internet, via social media applications (Twitter, Telegram, WhatsApp, Snap chat), and sending it via emails. The link was available for 3 days. During this time, the number of participants achieved 160 persons. Data utilization was done concerning each section; for example, in the 2 nd section, 41 participants were excluded by the question criteria.

Research instruments. The questionnaire included demographic information (gender, age, years of experience in the private sector, current level of management, organization size, and city), plus three 3 sections of five scale questions that meet the study's objectives as follows:

- Section 1: Included 7 questions about whether the lack of alternatives positively impacts the adoption intent of e-commerce during the COVID-19 crisis.

- Section 2: Included 2 questions about whether the perceived ease of use has a positive implication on the adoption intent of consumers during the COVID-19 crisis.

- Section 3: Included 6 questions about the factors that led to losses of many businesses during the COVID-19 crisis.

A 5-point Likert scale was used. The choices range from strongly disagree to agree strongly, which helps to get a holistic view of people's opinions (Table 1).

Table 1. Five-points Likert scale for agreement

\begin{tabular}{ccc}
\hline Description & Likert scale & Score interval \\
\hline Strongly disagree & 1 & $1.00-1.79$ \\
Disagree & 2 & $1.80-2.59$ \\
Neutral & 3 & $2.60-3.39$ \\
Agree & 4 & $3.40-4.19$ \\
Strongly agree & 5 & $4.20-5.00$ \\
\hline
\end{tabular}

Sources: developed by the authors.

The validity of the questionnaire was tested on several levels. Pilot testing of the questionnaire was performed to test validity, where 19 participants were recruited to investigate the ability of the respondents to complete the questionnaire, assess the clarity of the questions and the need to add or delete. For testing 
reliability, the internal consistency was evaluated by Cronbach's alpha test of the questionnaire; it was acceptable as Cronbach's alpha of the total scale was 0.710 . Three considerations were addressed in this study. Firstly, privacy and confidentiality guarantee all the information collected in this research is used only for the research and kept confidential. Also, ensuring they were knowledgeable that any of the information resulting from the research is to be used for presentations or reports. The second concern is safety, by confirming that the research is not harmful and certifying proper use of information. The third consideration is dignity, by ensuring that all participants were treated with great respect and each one has the freedom to make their own fully informed decisions.

Analysis was achieved through the SPSS (Statistical Package for the Social Sciences), IBM Corp, Armonk, NY, USA, version 27.

Results. This study included 160 workers in the e-commerce market in Saudi Arabia. The highest percentage was male (66.2\%), while the rest were females (33.8\%). 56.2\% the participants' aged $30-40$ years $(n=90), 31.9 \%$ aged under 30 years $(n=51)$, and $11.9 \%$ aged $41-50$ years $(n=19)$. Regarding the years of experience in the private sector, $38.75 \%$ of the participants $(n=62)$ have $5-10$ years of experience in the private sector, $36.25 \%(n=58)$ have less than 5 years, $11.25 \%(n=18)$ have $11-15$ year experience, and $13.75 \%(n=22)$ have more than 15 years experience. Concerning the participant's management level, the highest percentage was for middle-level managers $(41.9 \%)$, team members $(36.9 \%)$, and $18.1 \%$ were top-level managers. Regarding their organization size, the data revealed that the highest percentage, $40.6 \%$, is from companies that have above 500 employees, followed by $36.3 \%$ from companies with less than 250 employees, and $23.1 \%$ of them have $250-500$ employees. $43 \%$ of the participants are from Riyadh, $33.8 \%$ are from Jeddah, $9.4 \%$ are from Dammam, and $5.6 \%$ are from Makah (Table 2).

Table 2. The study participants' demographic characteristics

\begin{tabular}{lc}
\hline Characteristics & Frequency (n and \%) \\
\cline { 2 - 2 } Gender & All Participants (n= 160) \\
Male & $106(66.2 \%)$ \\
Female & $54(33.8 \%)$ \\
Age (Year) & \\
Less than 30 & $51(31.9 \%)$ \\
$30-40$ & $90(56.2 \%)$ \\
$41-50$ & $19(11.9 \%)$ \\
Experience in the private sector (Year) & \\
Less than 5 & $58(36.25 \%)$ \\
$5-10$ & $62(38.75 \%)$ \\
$11-15$ & $18(11.25 \%)$ \\
More than 15 & $22(13.75 \%)$ \\
The current level of management & \\
Top-level manager & $29(18.1 \%)$ \\
Middle-level managers & $67(41.9 \%)$ \\
Team members & $59(36.9 \%)$ \\
Other & $5(3.1 \%)$ \\
Employees number in the organization & \\
Less than 250 employees & $58(36.3 \%)$ \\
250-500 employees & $37(23.1 \%)$ \\
Above 500 employees & $65(40.6 \%)$ \\
\hline
\end{tabular}


Continued Table 2

\begin{tabular}{lc}
\hline Participants' cities & \\
Riyadh & $69(43.1 \%)$ \\
Makah & $9(5.6 \%)$ \\
Jeddah & $54(33.8 \%)$ \\
Dammam & $15(9.4 \%)$ \\
Other & $13(8.1 \%)$ \\
\hline
\end{tabular}

Sources: developed by the authors.

To establish whether lack of alternatives positively impacts the adoption intent of using e-commerce during the COVID-19 pandemic.

Table 3 and Figure 1 show the effect of the alternatives deficiency on the adoption intent of ecommerce during the COVID-19 pandemic. The results revealed that the highest average was awarded for question 3 about shifting sales from stores to online during the COVID-19 crisis with a mean of $3.76 \pm$ 1.22 with $30 \%$ strongly agreed and $40 \%$ agreed. While the lowest average to the question 4 which about reducing salaries since the start of COVID-19 with a mean of $2.65 \pm 1.37$, with strongly agree $13.1 \%$ and agree $16.2 \%$, while highest percentage $(26.9 \%)$ on the strong disagreement side, considering that the higher percentage of employees are from more prominent firms they could have faced fewer revenue issues. Question 5 about the relocation of employees was to address the concern that they may lose their jobs or change workspaces. The same concerns of closing up of traditional shops had neutral answers as well if the disagreement $(28.1 \%)$ is exceeded from the agreement $(27.5 \%)$. It explains how the stores had to keep working, still giving up salaries, and struggling to keep the traditional market alive.

The results of this section are most neutral among all the answers. The weighted average of section 1 was $3.19 \pm 0.75$, which indicated that the trend of establishment whether lack of alternatives has a positive implication on the intent of using e-commerce during the COVID-19 pandemic is neutral, as a general trend according to 5-point Likert scale as shown in Table 1 since 3.19 lay in the interval [2.603.39].

Table 3. Effect of alternatives deficiency on the adoption intent of using e-commerce during the COVID-19 pandemic

\begin{tabular}{|c|c|c|c|c|c|c|c|c|}
\hline Question & 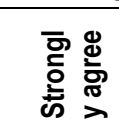 & 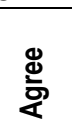 & 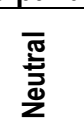 & 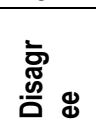 & $\begin{array}{l}\overline{\text { क }} \\
\text { ㅎํㄹ } \\
\text { के }\end{array}$ & 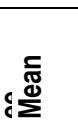 & 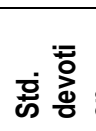 & ब্ \\
\hline 1 & 3 & 4 & 5 & 6 & 7 & 8 & 9 & 10 \\
\hline $\begin{array}{l}\text { My offline sales decreased in } 2020 \mathrm{~N} \\
\text { compared to the previous year } \%\end{array}$ & $\begin{array}{ll}23 \\
14.4\end{array}$ & $\begin{array}{l}58 \\
36.2\end{array}$ & $\begin{array}{l}27 \\
16.9\end{array}$ & $\begin{array}{l}31 \\
19.4\end{array}$ & $\begin{array}{l}21 \\
13.1\end{array}$ & 3.19 & 1.28 & Neutral \\
\hline $\begin{array}{l}\text { E-commerce revenue was higherN } \\
\text { trending during the COVID-19\% } \\
\text { crisis. }\end{array}$ & $\begin{array}{l}48 \\
30\end{array}$ & $\begin{array}{l}53 \\
33.1\end{array}$ & $\begin{array}{l}30 \\
18.8\end{array}$ & $\begin{array}{l}16 \\
10\end{array}$ & $\begin{array}{l}13 \\
8.1\end{array}$ & 3.67 & 1.23 & Agree \\
\hline $\begin{array}{l}\text { I have seen sales shift from storesN } \\
\text { to online during the COVID-19\% } \\
\text { crisis }\end{array}$ & $\begin{array}{l}48 \\
30\end{array}$ & $\begin{array}{l}64 \\
40\end{array}$ & 15.6 & $\begin{array}{l}7 \\
4.4\end{array}$ & $\begin{array}{l}16 \\
10\end{array}$ & 3.76 & 1.22 & Agree \\
\hline $\begin{array}{l}\text { Your company has had to reduceN } \\
\text { salaries since the start of COVID-\% } \\
19 .\end{array}$ & $\begin{array}{l}21 \\
13.1\end{array}$ & $\begin{array}{l}26 \\
16.2\end{array}$ & $\begin{array}{l}32 \\
20\end{array}$ & $\begin{array}{l}38 \\
23.8\end{array}$ & $\begin{array}{l}43 \\
26.9\end{array}$ & 2.65 & 1.37 & Neutral \\
\hline $\begin{array}{l}\text { Your company has had to relocateN } \\
\text { staff since the start of COVID-19. \% }\end{array}$ & $\begin{array}{l}14 \\
8.8\end{array}$ & $\begin{array}{l}44 \\
27.5 \\
\end{array}$ & $\begin{array}{l}37 \\
23.1\end{array}$ & $\begin{array}{l}45 \\
28.1\end{array}$ & $\begin{array}{l}20 \\
12.5\end{array}$ & 2.92 & 1.19 & leut \\
\hline
\end{tabular}




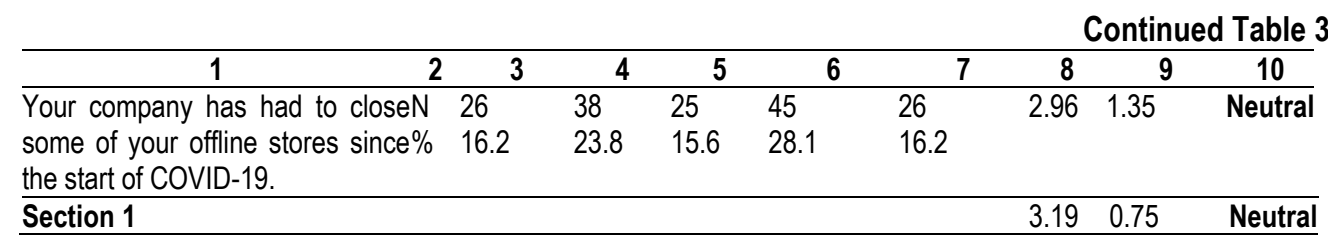

Sources: developed by the authors.

Your company had to close some of your offline store since start of Covid-19.

Your company had to relocate staff since start of Covid-19.

Your company had to reduce salaries since start of Covid-19.

I have seen sales shift from stores to online during the COVID-19 crisis

E-commerce revenue was higher trending during the COVID-19 crisis.

The sales of my offline sales decreased in 2020 compares to previous year

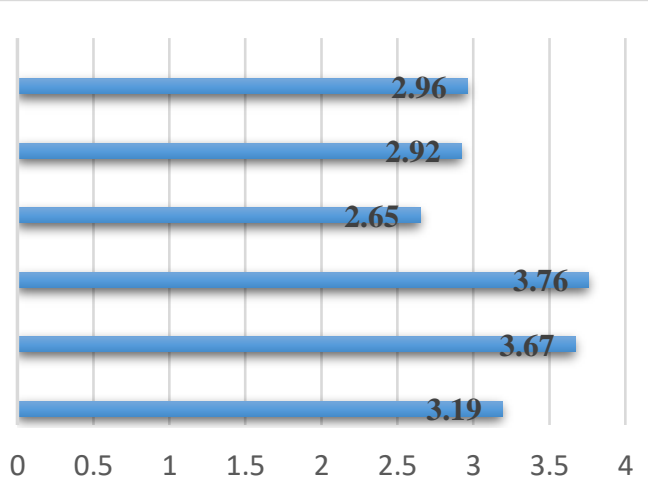

Figure 1. The weighted average of the six questions in section 1

Sources: developed by the authors.

Table 4. shows the answer to the question of implemented work from home. The results revealed that most of the participants said yes $(86.3 \%)$.

Table 4. If the company implemented work from home during the crisis

\begin{tabular}{ccc}
\hline $\begin{array}{c}\text { Has the company implemented a work } \\
\text { from home option during the crisis? }\end{array}$ & Frequency & Percentage \\
\hline Yes & 138 & 86.3 \\
No & 22 & 13.7 \\
\hline
\end{tabular}

Sources: developed by the authors.

Section 2: To determine whether the perceived ease of use has a positive implication on the adoption intent of consumers during a COVID-19 outbreak

Table 5 shows the answer to the question about the effect of companys' practices on the consumers' adoption intent of using e-commerce during the crisis. The results showed that $25.6 \%$ of the participants said other practices (not mentioned), $21.9 \%$ practice mobile apps, $18.8 \%$ practice the whole e-commerce infrastructure, and $15.6 \%$ practice home delivery. In contrast, touchless payment was the lowest $(6.2 \%)$.

Table 5. Effect of company's practices on the consumers' adoption intent of using e-commerce during the COVID-19 pandemic

\begin{tabular}{lccc}
\hline What new practices does your company introduce due to COVID-19? & Frequency & Percentage \\
\hline & $\mathbf{1}$ & $\mathbf{2}$ & $\mathbf{3}$ \\
\hline Whole e-commerce infrastructure & 30 & 18.8 \\
Home delivery & 25 & 15.6 \\
Mobile apps & 35 & 21.9 \\
\hline
\end{tabular}


Continued Table 5

\begin{tabular}{|c|c|c|}
\hline 1 & 2 & 3 \\
\hline Touchless payment & 10 & 6.2 \\
\hline Shut down some physical stores for good & 19 & 11.9 \\
\hline Other & 41 & 25.6 \\
\hline
\end{tabular}

Sources: developed by the authors.

Table 6. Sales shift from stores to online during the COVID-19 crisis

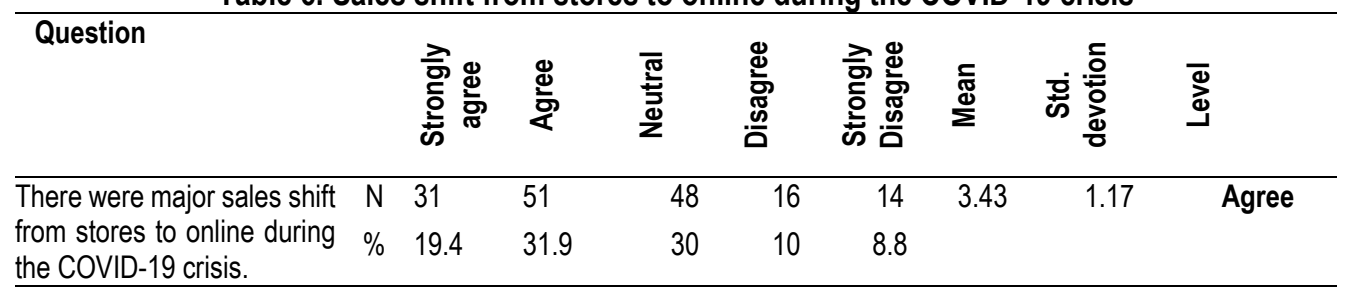

Sources: developed by the authors.

Table 6 shows descriptive statistics for section 2. Data revealed that $31.9 \%$ of participants agreed, $30 \%$ were neutral, and $19.4 \%$ strongly agreed. The weighted average of section 2 was $3.43 \pm 1.17$, which indicated that the trend of determining whether the perceived ease of use has a positive implication on the adoption intent of consumers using e-commerce during a COVID-19 outbreak is «Agree», according to the 5-point Likert scale since 3.43 lie in the interval [3.40-4.19].

From this section which aimed to investigate if the apparent ease of use has a positive impact on consumers' intent for using e-commerce, there are two questions in this section addressing the new company's practices by which were adopted online aid selling. And the second question for participants is if they noticed a significant shift in sales during the pandemic. Both questions can affect each other where question two will state an observed shift, while question one will identify the factor that mainly got adopted to execute the change in the market.

In the first question in section 2, the highest frequency variable is "others» $(25.9 \%)$ which wasn't declared and cannot be analyzed. Then comes mobile apps with a total percentage of 21.9 , which is a noticeable percent, and $18.8 \%$ confirms that they introduced the whole e-commerce infrastructure. Touchless payment had a minor percentage of all $(6.2 \%)$. With all these new adoptions, the market still changed to a small percentage, but many firms have adopted new methodologies to avoid spreading the virus. Also, the results of the second question agree that sales were majorly shifted online. Hence the results of section two indicate an agreement on the positive impact on the adoption intent of consumers for using e-commerce during the crisis.

Section 3: To explore the underlying factors that lead to losses of many businesses during the COVID19 crisis

Table 7 and Figure 2 show the underlying factors that lead to the losses of many businesses during the crisis. Results revealed that the highest average was awarded to question 1, which was about the money management was the main challenge with a mean of $3.61 \pm 1.15$ with strongly agree by $23.8 \%$ and agree by $36.2 \%$. While the lowest average to question 4 , which was about paying employees' salaries, was the main challenge with a mean of $3.06 \pm 1.36$, with a strongly agree by $18.1 \%$ and agree by $23.8 \%$. The weighted average of section (3) was $3.29 \pm 0.90$, which indicated that the trend of "To explore the underlying factors that lead to losses many businesses during the crisis" is (Neutral) according to 5-point Likert scale, thus consider a moderate level. Moreover, the highest percentage of participants said their company was not preparing for another lockdown by $56.2 \%$, while only $43.8 \%$ of them said (Yes) (Table 8). 
Table 7. Factors lead to losses of many businesses during the COVID-19 crisis

\begin{tabular}{|c|c|c|c|c|c|c|c|c|c|}
\hline Questions & & $\begin{array}{l}\text { ㅊㅎㅀ ฏ } \\
\text { 잏 } \\
\text { क }\end{array}$ & 巡 & 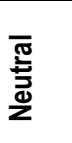 & 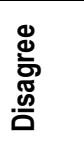 & 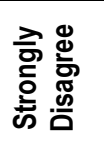 & $\stackrel{\varpi}{\varpi}$ & के & ळ্ \\
\hline $\begin{array}{l}\text { Money management was the main } \\
\text { challenge for your company during COVID- } \\
19 .\end{array}$ & $\begin{array}{l}\mathrm{N} \\
\%\end{array}$ & $\begin{array}{c}38 \\
23.8\end{array}$ & $\begin{array}{c}58 \\
36.2\end{array}$ & $\begin{array}{c}41 \\
25.6\end{array}$ & $\begin{array}{l}10 \\
6.2\end{array}$ & $\begin{array}{l}13 \\
8.1\end{array}$ & 3.61 & 5 & Agree \\
\hline $\begin{array}{l}\text { Going digital was the main challenge for } \\
\text { your company because of COVID- } 19 \text {. }\end{array}$ & $\begin{array}{l}\mathrm{N} \\
\%\end{array}$ & $\begin{array}{l}15 \\
9.4\end{array}$ & $\begin{array}{c}58 \\
36.2\end{array}$ & $\begin{array}{c}46 \\
28.8\end{array}$ & $\begin{array}{c}27 \\
16.9\end{array}$ & $\begin{array}{l}14 \\
8.8\end{array}$ & 3.21 & 1.11 & Neutral \\
\hline $\begin{array}{l}\text { Paying fixed expenses was the main } \\
\text { challenge for your company because of } \\
\text { COVID- } 19 \text {. }\end{array}$ & $\begin{array}{l}\mathrm{N} \\
\%\end{array}$ & $\begin{array}{l}15 \\
9.4\end{array}$ & $\begin{array}{c}45 \\
28.1\end{array}$ & $\begin{array}{c}62 \\
38.8\end{array}$ & $\begin{array}{c}20 \\
12.5\end{array}$ & $\begin{array}{c}18 \\
11.2\end{array}$ & 3.12 & 1.11 & Neutral \\
\hline $\begin{array}{l}\text { Paying employees' salaries was the main } \\
\text { challenge for your company because of } \\
\text { COVID- } 19 \text {. }\end{array}$ & $\begin{array}{l}\mathrm{N} \\
\%\end{array}$ & $\begin{array}{c}29 \\
18.1\end{array}$ & $\begin{array}{c}38 \\
23.8\end{array}$ & $\begin{array}{c}35 \\
21.9\end{array}$ & $\begin{array}{c}31 \\
19.4\end{array}$ & $\begin{array}{c}27 \\
16.9\end{array}$ & 3.06 & 1.36 & Neutral \\
\hline $\begin{array}{l}\text { Loss of sales was the main challenge for } \\
\text { your company because of COVID-19. }\end{array}$ & $\begin{array}{l}\mathrm{N} \\
\% \\
\end{array}$ & $\begin{array}{c}37 \\
23.1 \\
\end{array}$ & $\begin{array}{c}47 \\
29.4 \\
\end{array}$ & $\begin{array}{c}38 \\
23.8 \\
\end{array}$ & $\begin{array}{l}24 \\
15 \\
\end{array}$ & $\begin{array}{l}14 \\
8.8 \\
\end{array}$ & 3.43 & 1.24 & Agree \\
\hline Section 3 & & & & & & & 3.29 & 0.90 & Neutral \\
\hline
\end{tabular}

Sources: developed by the authors.

Loss of sales was a main challenge for your company because of Covide-19.

Paying employees' salaries was a main challenge for your company because of Covide-19.

Paying fixed expenses was a main challenge for your company because of Covide-19.

Going digital was a main challenge for your company because of Covide-19.

Money Management was a main challenge for your company because of Covide-19.

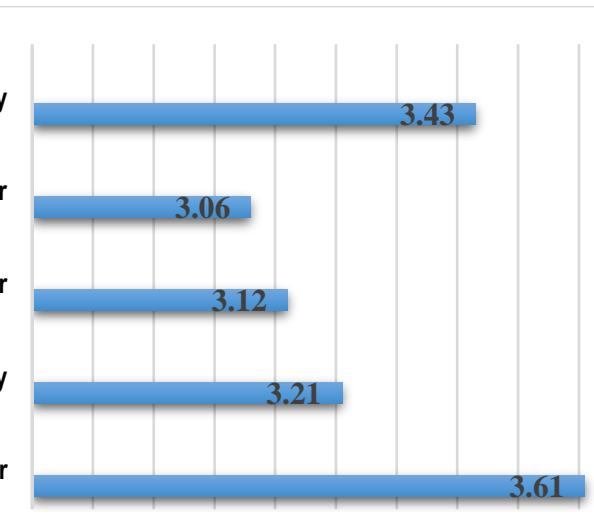

$\begin{array}{lllllllllll}2.7 & 2.8 & 2.9 & 3 & 3.1 & 3.2 & 3.3 & 3.4 & 3.5 & 3.6 & 3.7\end{array}$

Figure 2. The weighted average of the five questions in section 3

Sources: developed by the authors.

Table 8. Preparing the company for another lockdown

\begin{tabular}{lcc}
\hline Are your company preparing for another lockdown? & Frequency & Percentage \\
\hline Yes & 70 & 43.8 \\
No & 90 & 56.2 \\
\hline
\end{tabular}

Sources: developed by the authors.

This study provides adequate factors supporting the need for e-commerce marketing in this growing world of social media in sections one and two. There was an average trend of people who saw the market shift happening. A moderate percentage of participants agreed that the pandemic affected their sales. Sums up that the result of the crisis was bad, but all factors neutralized each other to some extent. Most 
employees agree with the increased revenue of the e-commerce market. When connecting these two points, if the participants think that the revenue of online marketing increased, it indicates that the revenue of the traditional market came way down.

The last questionnaire section aimed to point out the factors that caused losses of different businesses. The most frequent answer was «money management problems» due to the pandemic and new ecommerce trend, many firms had to readjust their priorities, which created money management issues. The second problem that was considered the reason for loss among participants was reduced sales during the pandemic. As every market and workplace was closed, the demand for normal goods decreased. Going digital as a major problem, payment of fixed expenses and employee pay were 3rd, 4th, and 5th issues causing loss respectively. Most answers were by participants who agreed that their firms were not ready for another pandemic.

Previous studies indicated that the decline of conventional retail sales is due to increased e-retailer customers in Saudi Arabia Facts and Statistics (Statista, 2017). Rising retailer's performance trends posed a significant threat to the conventional retail stores in Saudi Arabia (Rahman, 2014). The significant diffusion of e-commerce has prompted many studies investigating the drivers and motivators of competitive e-commerce utilization and e-commerce deployment from various aspects. Explore individuallevel factors, with a relatively minor focus on organizational aspects (Al-mani, 2020; Hoq, 2020).

Rainer and Cegielski (2010) found that e-commerce offers consumers innovative ways of acquiring products and services. Individuals' most significant drivers of e-commerce adoption are access to a wide variety of products in the worldwide market. Moreover, Steel et al. (2013) report that the security of transactions conducted over reliable payment gateways has further facilitated e-commerce adoption. Apart from that, an individual enjoys substantial convenience in terms of time, price, product quality, and transportation of goods compared to conventional businesses. The e-trailing trend in Saudi Arabia picked up and gained momentum during the corona period due to social isolation. The direction was expedited by regular restaurants, fast foods, as well as other retailers who used various mobile applications intended to divert the attention of the customers and also adopt new trends that are provided by trends in e-business (Alkenani, 2019)

Conclusions. This study investigated the impacts of factors derived by COVID-19 had on the ecommerce market of Saudi Arabia. From the obtained data, it is analyzed that there was a shift of shopping trend towards the online market due to that trend, businesses had to bear the loss. There were different kinds of tactics adopted by businessmen all over the country for going online during the pandemic to cope with the situation. All these new measures returned to a growing e-commerce market.

The results of this analysis could be utilized for examining opinions about e-commerce and whether the public wanted to switch from offline to online mode of marketing. The demerits of e-commerce enlisted in this research can be utilized by the owners of small and large businesses to upgrade their online businesses to attract more people to them.

Therefore, incompatible with the 2030 Vision that strives to boost the role of technologies and empower faster innovations as e-commerce to enhance the quality of services, increase users' satisfaction and improve the quality of life for Saudi Arabia citizens and residents. It could be recommended that entrepreneurs invest in e-commerce and their applications rather than offline stores to enhance services quality and gain profit. A lack of alternatives negatively impacts consumer purchase intent during the pandemic. Also, they need to improve the ease of using online stores and their applications to increase the usage of e-commerce through advertising and marketing power.

Authors' contributions: conceptualization, S. A and L. A; formal analysis, L. A; funding acquisition, S. A; investigation, L. A; methodology, S. A and L. A; project administration, S. A; resources, S. A and L. A; supervision, S. A; visualization, S. A; writing original draft, L. A; writing-review and editing, S. A.

Funding: This research received no external funding. 


\section{References}

$\mathrm{ACl}$. (2020). ACI worldwide research reveals increase in June e-commerce sales-largest since the start of COVID-19 pandemic restrictions. Retrieved from [Link]

Alflayyeh, S., \& Belhaj, F. A. (2020). The Impact Of Coronavirus (Covid-19) Pandemic On Retail Business In Saudi Arabia: A Theoretical Review. European Journal of Molecular \& Clinical Medicine, 7(1), 3547-3554. [Google Scholar]

Alkenani, A. A. N. (2019, March). Factors Influencing Social E-Commerce Success in Saudi Arabia-A Review. In 20196 th International Conference on Computing for Sustainable Global Development (INDIACom) (pp. 1331-1335). IEEE. [Google $\underline{\text { Scholar] }}$

Al-mani, K. (2020). The Impact of E-commerce on the Development of Entrepreneurship in Saudi Arabia. Journal of International Technology and Information Management, 28(4), 28-62. [Google Scholar]

Barnes, S. J. (2020). Information management research and practice in the post-COVID-19 world. International Journal of Information Management, 55, 102175. [Google Scholar] [CrossRef]

Dholakia, U. M., Kahn, B. E., Reeves, R., Rindfleisch, A., Stewart, D., \& Taylor, E. (2010). Consumer behavior in a multichannel, multimedia retailing environment. Journal of interactive marketing, 24(2), 86-95. [Google Scholar] [CrossRef]

Dryhurst, S., Schneider, C. R., Kerr, J., Freeman, A. L., Recchia, G., Van Der Bles, A. M., ... \& Van Der Linden, S. (2020) Risk perceptions of COVID-19 around the world. Journal of Risk Research, 23(7-8), 994-1006. [Google Scholar] [CrossRef]

Ezzi, S. W. (2016). Exploring the characteristics of the e-commerce marketplace in Saudi Arabia. International Journal of Economic Perspectives, 10(4), 5-20. [Google Scholar]

Feichtinger, S., \& Gronalt, M. (2021). The Environmental Impact of Transport Activities for Online and In-Store Shopping: A Systematic Literature Review to Identify Relevant Factors for Quantitative Assessments. Sustainability, 13(5), 2981. [Google Scholar] [CrossRef

Grashuis, J., Skevas, T., \& Segovia, M. S. (2020). Grocery shopping preferences during the COVID-19 pandemic. Sustainability, 12(13), 5369. [Google Scholar] [CrossRef]

Habib, S., \& Hamadneh, N. N. (2021). Impact of perceived risk on consumers technology acceptance in online grocery adoption amid covid-19 pandemic. Sustainability, 13(18), 10221. [Google Scholar] [CrossRef]

Havrlant, D., Darandary, A. \& Muhsen, A. (2021). Early estimates of the impact of the Covid-19 pandemic on GDP: a case study of Saudi Arabia. Appli Economic, 53(12).1317-1325. [CrossRef

Hoq, M. Z. (2020). The management of e-commerce in the Kingdom of Saudi Arabia: An exploratory research. Manag, 53(12):1317-1325. Retrieved from [Link]

Illankoon, K. (2020). E-Commerce demand rises in Saudi Arabia due to Covid-19: Oxford Business Group. Construction Business News. Retrieved from [Link]

Koch, J., Frommeyer, B., \& Schewe, G. (2020). Online shopping motives during the COVID-19 pandemic-lessons from the crisis. Sustainability, 12(24), 10247. [Google Scholar] [CrossRef]

Le, H. T., Carrel, A. L., \& Shah, H. (2021). Impacts of online shopping on travel demand: a systematic review. Transport Reviews, 1-23. [Google Scholar] [CrossRef

López Soler, J. R., Christidis, P., \& Vassallo, J. M. (2021). Teleworking and Online Shopping: Socio-Economic Factors Affecting Their Impact on Transport Demand. Sustainability, 13(13), 7211. [Google Scholar] [CrossRef]

Manh, T. H., Anh, N. N., Duc, N. T., Minh, N. B., Huong, M. T., \& Hieu, N. M. (2021). Adherence to mask wearing on public transport during the COVID-19 pandemic and influential factors: The case of Hanoi. Tạp chi Khoa học Giao thông vận tải, 72(4), 486-497. [Google Scholar] [CrossRef]

Market Watch. (2020). E-commerce market size, rising impact of Covid-19, product scope, 2019 demand and sales analysis to 2026. Market Watch. Retrieved from [Link]

Melis, K., Campo, K., Breugelmans, E., \& Lamey, L. (2015). The impact of the multi-channel retail mix [Google Scholar [CrossRef

Nguyen, M. H., Armoogum, J., \& Nguyen Thi, B. (2021). Factors affecting the growth of e-shopping over the covid-19 era in hanoi, vietnam. Sustainability, 13(16), 9205. [Google Scholar] [CrossRef]

Pantano, E., Pizzi, G., Scarpi, D., \& Dennis, C. (2020). Competing during a pandemic? Retailers' ups and downs during the COVID-19 outbreak. Journal of Business Research, 116, 209-213. [Google Scholar] [CrossRef]

Rahman, M. N. (2014). A study on Saudi Arabian retail dynamics, its potential future and challenges. International Journal of Business and Economic Development (IJBED), 2(1). [Google Scholar]

Rainer Jr, R.K. \& Cegielski, C.G. (2010). Introduction to information systems, $3^{\text {rd }}$ ed. John Wiley and sons, New Jersey, USA. Retrieved from [Link]

Salem, M. A., \& Nor, K. M. (2020). The effect of COVID-19 on consumer behaviour in Saudi Arabia: Switching from brick and mortar stores to E-Commerce. International Journal of Scientific \& Technology Research, 9(07), 15-28. [Google Scholar]

Schmid, B., \& Axhausen, K. W. (2019). In-store or online shopping of search and experience goods: A hybrid choice approach. Journal of choice modelling, 31, 156-180. [Google Scholar] [CrossRef]

Statista. (2017). Saudi Arabia Facts and Statistics. Retrieved from [Link] 
Steel, W., Daglish, T., Marriott, L., Gemmell, N., \& Howell, B. (2013). E-Commerce and its effect upon the Retail Industry and Government Revenue (No. 4333). Victoria University of Wellington, The New Zealand Institute for the Study of Competition and Regulation. [Google Scholar]

Vasić, N., Kilibarda, M., \& Kaurin, T. (2019). The influence of online shopping determinants on customer satisfaction in the Serbian market. Journal of theoretical and applied electronic commerce research, 14(2), 70-89. [Google Scholar] [CrossRef]

Villa, E., Ruiz, L., Valencia, A., \& Picón, E. (2018). Electronic commerce: factors involved in its adoption from a bibliometric analysis. Journal of theoretical and applied electronic commerce research, 13(1), 39-70. [Google Scholar] [CrossRef]

WHO (2020). Getting your workplace ready for COVID-19; World Health Organization: Geneva, Switzerland, 2020. [Link]

Сайя Албліві, Ph.D., Університет короля Абдельазіз, Саудівська Аравія

Ліінах А. Алсаламі, Університет короля Абдельазіз, Саудівська Аравія

Електронна комерція в період пандемії COVID-19: новітні тренди та перспективи для Саудівської Аравії

Ця стаття узагальнює аргументи та контраргументи в межах наукової дискусії з питання поширення у світі електронної комерції завдяки наслідкам пандемії Covid-19. Основною метою проведеного дослідження є визначення факторів змін в розвитку електронної комерції Саудівської Аравії. Систематизація літературних джерел та підходів до розв'язання поставленої проблеми дозволила висунути гіпотезу, що пандемія COVID-19 стала каталізатором нової хвилі зростання темпів збільшення обсягів електронної торгівлі в Саудівській Аравії. Для перевірки висунутої гіпотези проведено анкетування 160 респондентів, які працюють у сфері приватної електронної комерції. До анкети включено питання щодо визначення демографічного профілю респондентів та розвитку електронної комерції. Оцінювання відповідей трьох блоків питань, щодо розвитку електронної комерції здійснювалося за п'яти бальною шкалою Лейкарта. Більшість учасників анкетування $є$ чоловіками - 66,2\%. 56,2\% учасників є віком від 30 до 40 років; 38,75\% - мають 5-10 річний стаж роботи в приватному бізнесі, 40,6\% - мають досвід роботи у компаніях з чисельністю понад 500 осіб, 43\% - проживають у місті Ер-Ріяд. За результатами опрацювання відповідей першого блоку питань анкети щодо розвитку електронної комерції встановлено, що відсутність альтернатив має статистично не значущий вплив на наміри споживачів здійснювати купівлі на електронному ринку (середньозважене значення - $3.19 \pm 0.75$ ). Результати аналізу відповідей другого блоку питань свідчать про те, що доступність до засобів електронної комерції має позитивний вплив на готовність споживачів здійснювати онлайн-покупки (середньозважене значення - 3,43 $\pm 1,17$ ). Аналіз відповідей третього блоку питань засвідчив, що дослідження головних причин збитків під час пандемії COVID-19 є статистично не значущими для електронної комерції (середньозважене значення - 3,29 \pm 0,90). До того, більшість учасників анкетування $(56,2 \%)$ зазначили, що їх компанії були не готовими до чергової хвилі карантинних обмежень. Результати дослідження мають практичне значення та можуть бути основою для подальшого аналізу впливу COVID-19 на різні сегменти електронного ринку. Отримані результати можуть бути використані для визначення рівня сприйняття населенням особливостей електронної комерції та бажання здійснювати купівлі в інтернетмагазинах.

Ключові слова: електронна комерція, COVID-19, споживачі, ринок, Саудівська Аравія. 